\title{
Unusually strong temperature dependence of P2X3 receptor traffic to the plasma membrane
}

\author{
E. Pryazhnikov ${ }^{1}$, D. Fayuk ${ }^{2}$, M. Niittykoski ${ }^{2}$, Rashid Giniatullin ${ }^{2 *}$ and Leonard Khiroug ${ }^{*}{ }^{* t}$ \\ Neuroscience Center, University of Helsinki, Helsinki, Finland \\ ${ }^{2}$ Department Neurobiology, A. I. Virtanen Institute for Molecular Sciences, University of Eastern Finland, Kuopio, Finland
}

\section{Edited by:}

Dieter Wicher, Max Planck Institute for Chemical Ecology, Germany

\section{Reviewed by:}

Alexej Verkhratsky, University of Manchester, UK

Felix Viana, Spanish Council of Scientific Research, Spain

\section{${ }^{*}$ Correspondence:}

Rashid Giniatullin, Department Neurobiology, A. I. Virtanen Institute for Molecular Sciences, University of Eastern Finland, PO Box

1627/Neulaniementie 2, 70211

Kuopio, Finland.

e-mail: rashid.giniatullin@uef.fi; Leonard Khiroug, Neuroscience Center, University of Helsinki, PO Box 56 (Viikinkaari 4), Fl-00014 Helsinki,

Finland.

e-mail: leonard.khirug@helsinki.fi

${ }^{\dagger}$ Rashid Giniatullin and Leonard Khiroug have contributed equally to this work.
ATP-gated P2X3 receptors are expressed by nociceptive neurons and participate in transduction of pain. Responsiveness of P2X3 receptors is strongly reduced at low temperatures, suggesting a role for these receptors in analgesic effects of cooling. Since sustained responsiveness depends on receptor trafficking to the plasma membrane, we employed total internal reflection fluorescence (TIRF) microscopy to highlight perimembrane pool of DsRed-tagged P2X3 receptors and studied the effects of temperature on perimembrane turnover of P2X3-DsRed. Patch-clamp recordings confirmed membrane expression of functional, rapidly desensitizing P2X3-DsRed receptors. By combining TIRF microscopy with the technique of fluorescence recovery after photobleaching (FRAP), we measured the rate of perimembrane turnover of P2X3-DsRed receptors expressed in hippocampal neurons. At room temperature, the P2X3-DsRed perimembrane turnover as measured by TIRF-FRAP had a time constant of $\sim 2 \mathrm{~min}$. At $29^{\circ} \mathrm{C}$, receptor turnover was strongly accelerated $(0.6 \mathrm{~min})$, yielding an extremely high temperature dependence coefficient $\mathrm{Q}_{10} \sim 4.5$. In comparison, AMPA receptor turnover measured with TIRF-FRAP was only moderately sensitive to temperature $\left(\mathrm{Q}_{10} \sim 1.5\right)$. The traffic inhibitor Brefeldin $A$ selectively decelerated P2X3-DsRed receptor turnover at $29^{\circ} \mathrm{C}$, but had no effect at $21^{\circ} \mathrm{C}\left(\mathrm{Q}_{10} \sim 1.0\right)$. This indicates that receptor traffic to plasma membrane is the key temperature-sensitive component of P2X3 turnover. The selective inhibitor of the RhoA kinase Y27632 significantly decreased the temperature dependence of $P 2 X 3-D s R e d$ receptor turnover $\left(Q_{10} \sim 2.0\right)$. In summary, the RhoA kinase-dependent membrane trafficking of $\mathrm{P} 2 \mathrm{X} 3$ receptors to plasma membrane has an exceptionally high sensitivity to temperature. These findings suggest an important role of P2X3 receptor turnover in hypothermia-associated analgesia.

Keywords: ligand gated receptors, receptor trafficking, P2X3 receptor, temperature, pain

\section{INTRODUCTION}

Extracellular ATP is recognized as a ubiquitous neurotransmitter and neuromodulator operating via metabotropic P2Y or/and ionotropic P2X receptors (Burnstock, 2006). P2X receptors (encoded by $P 2 X R 1-7$ genes) are non-selective cationic channels expressed in various tissues including peripheral and central nervous system (Burnstock, 2007). The P2X3 subtype of ATP-gated receptors is expressed mostly in sensory neurons and is involved in transduction of pain stimuli, especially in inflammatory and cancer pain models (Burnstock, 2000; Chizh and Illes, 2001; Jarvis and Kowaluk, 2001; McGaraughty et al., 2003; North, 2004). One unusual property of these receptors is their rapidly developing and extremely long-lived desensitization which lasts up to $20 \mathrm{~min}$ at room temperature (Cook et al., 1998). This property raises an issue of how these receptors can perform their role in pain transduction if they are silent for many minutes after a single activation (Cook et al., 1998). A clue to this paradox was provided by the findings that elevated temperatures specifically accelerated P2X3 receptor resensitization (Cook and McCleskey, 2001), and that this temperature dependence was exceptionally high with the $\mathrm{Q}_{10}$ coefficient of $\sim 10$ (Khmyz et al., 2008).
Besides desensitization/resensitization, another factor affecting sustained responsiveness and plastic receptor changes during chronic pain states is receptor trafficking to (and from) plasma membrane (reviewed in Liu and Salter, 2010). For example, membrane recycling of a well studied AMPA-type glutamate receptor is involved in chronic pain (Latremoliere and Woolf, 2009) and in long-term potentiation (LTP; Derkach et al., 2007), and is known to depend on scaffolding proteins such as PICK-1 and the cytoskeleton. In contrast to AMPA receptors, the rate of P2X3 receptor membrane recycling and mechanisms of its regulation remain largely unknown. Adding a further layer of complexity, current evidence suggests that members of P2X receptors subfamily differ in their trafficking properties. Thus, P2X4 receptors are more prone to rapid constitutive internalization/reinsertion into the plasma membrane than P2X2, indicating involvement of subunit-specific trafficking mechanisms (Bobanovic et al., 2002). We have previously suggested that accelerated insertion of P2X3 receptors in the membrane is the main mechanism underlying sensitization of trigeminal neurons in migraine-like states (Fabbretti et al., 2006; Giniatullin et al., 2008). While the well established role of P2X3 receptors in migraine and other types of chronic 
pain makes them an attractive candidate for mediating analgesic effects of cooling, the temperature dependence of $\mathrm{P} 2 \mathrm{X} 3$ receptor trafficking has not been studied until now.

We set out to evaluate the recycling rate of $\mathrm{P} 2 \mathrm{X} 3$ receptors and to explore temperature dependence of the perimembrane turnover of $\mathrm{P} 2 \mathrm{X} 3$ receptors. To this end, we combined total internal reflection fluorescence (TIRF) imaging with photobleaching (TIRF-FRAP, total internal reflection fluorescence recovery after photobleaching; Sund and Axelrod, 2000; Pochynyuk et al., 2007). This approach allowed us to selectively bleach the perimembrane pool of DsRed-tagged $\mathrm{P} 2 \mathrm{X} 3$ receptors and to assess the kinetics of receptor turnover by measuring the rate of perimembrane fluorescence recovery after photobleaching (FRAP). We report the remarkably high temperature dependence $\left(\mathrm{Q}_{10} \sim 4.5\right)$ of $\mathrm{P} 2 \mathrm{X} 3$ receptor perimembrane turnover, which is in sharp contrast with the mild temperature dependence of AMPA receptors measured under the same TIRF-FRAP conditions. The rapid perimembrane turnover of $\mathrm{P} 2 \mathrm{X} 3$ receptors identified in this study potentially represents a druggable target to counteract chronic pain states that involve ATP-gated channels.

\section{RESULTS}

\section{MEMBRANE EXPRESSION OF P2X3-DsRed RECEPTORS}

To test whether tagging $\mathrm{P} 2 \mathrm{X} 3$ receptors with DsRed undermines its functional properties, we performed patch-clamp recordings from HEK-293 cells transfected with the P2X3-DsRed encoding plasmid. As shown in Figure 1A, application of $\alpha, \beta$-meATP $(10 \mu \mathrm{M})$ for $2 \mathrm{~s}$ via a rapid solution exchange system induced a large inward current with the mean amplitude of $420 \pm 160 \mathrm{pA}$ ( $n=5$ cells). The current decayed rapidly in the presence of the agonist with the time constant of $36 \pm 7 \mathrm{~ms}$, presumably due to $\mathrm{P} 2 \mathrm{X} 3$ receptor desensitization.

In order to compare $\mathrm{P} 2 \mathrm{X} 3-\mathrm{DsRed}$ receptor functional properties to these of (i) untagged $\mathrm{P} 2 \mathrm{X} 3$ and (ii) native $\mathrm{P} 2 \mathrm{X} 3$ receptors under the same experimental conditions, we performed patchclamp recordings from HEK-293 cells transfected with untagged P2X3 (Figure 1B) and from mouse cultured trigeminal neurons (Figure 1C). The peak current amplitude of untagged $\mathrm{P} 2 \mathrm{X} 3$ receptors was larger than that of both DsRed-tagged and native receptors $(3438 \pm 250$ versus $420 \pm 160$ and $650 \pm 130 \mathrm{pA}$, respectively; $P<0.05)$, indicating higher transfection efficiency for untagged $\mathrm{P} 2 \mathrm{X} 3$ receptors as compared to the DsRed-tagged ones. Importantly, desensitization kinetics was characteristically fast and did not differ significantly between DsRed-tagged, untagged, and native $\mathrm{P} 2 \mathrm{X} 3$ receptors (tau $36 \pm 7,69 \pm 16$, and $60 \pm 8 \mathrm{~ms}, n=5$, 6 , and 7, respectively; $P>0.05$, Figure $1 D$ ). We conclude that tagging $\mathrm{P} 2 \mathrm{X} 3$ receptors with DsRed did not influence significantly its functional properties, in agreement with previous reports (Grote et al., 2005).

\section{QUANTIFICATION OF PERIMEMBRANE TURNOVER OF P2X3-DsRed RECEPTORS USING TIRF-FRAP}

Next, we evaluated the rate of perimembrane turnover of P2X3DsRed receptors at room temperature. We chose as a model the embryonic hippocampal neurons which lack native $\mathrm{P} 2 \mathrm{X}$ receptors at this stage of development (Khakh et al., 2001), and

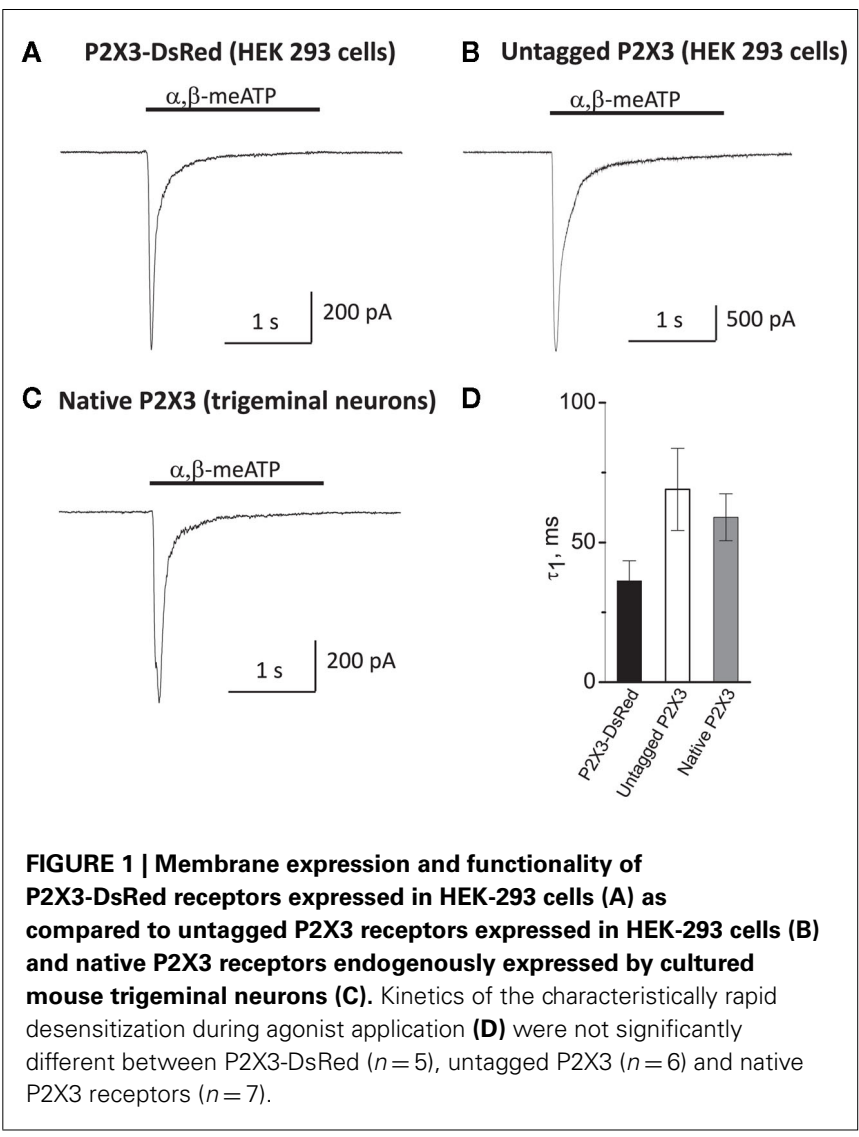

overexpressed P2X3-DsRed receptors in these cells. Use of total internal fluorescence (TIRF) microscopy allowed us to highlight those P2X3-DsRed that were proximal to basal plasma membrane by means of the so called evanescent field (Schmoranzer et al., 2000). We combined TIRF microscopy with the method of FRAP. This approach, termed TIRF-FRAP, has been developed to assess the kinetics of perimembrane trafficking of fluorescently tagged molecules (Sund and Axelrod, 2000) and used previously to evaluate perimembrane turnover of plasmalemmal ion channels (Pochynyuk et al., 2007). Prolonged exposure to the high intensity evanescent field results in selective photobleaching of perimembrane fluorescent molecules, whereas those intracellular fluorescent molecules that are further than approximately $100 \mathrm{~nm}$ away from the basal plasma membrane remain unbleached and retain their fluorescence. We photobleached perimembrane P2X3DsRed and measured the rate of fluorescence recovery, which we used as an index of the net movement of the unbleached P2X3-DsRed molecules toward plasma membrane (Figure 2). Dendritic and somatic regions were analyzed separately, with somatic data presented first (see below for the data on dendritic regions).

The degree of fluorescence recovery (termed "relative FRAP") constituted, on average, $65 \pm 7 \%$ of the pre-bleaching baseline level $(n=12)$. The rate of recovery in TIRF-FRAP had a time constant of $2.15 \pm 0.82 \mathrm{~min}(n=12)$. Thus, at room temperature, perimembrane recycling of $\mathrm{P} 2 \mathrm{X} 3$ receptors required $>10 \mathrm{~min}$ to reach a steady-state plateau. 


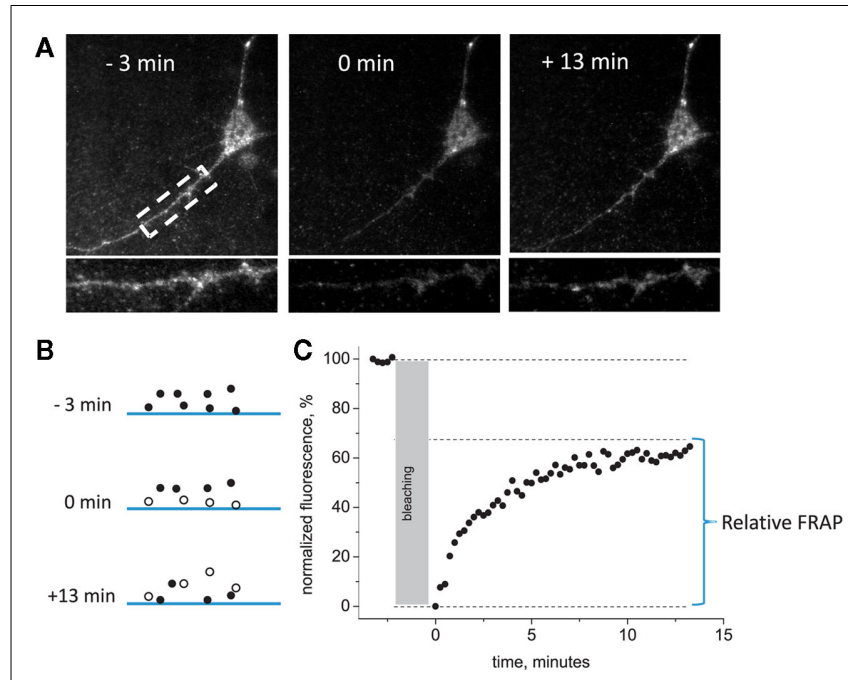

FIGURE 2 | General scheme of TIRF-FRAP experiments. (A)

Representative images of the hippocampal neuron expressing P2X3-DsRed acquired $3 \mathrm{~min}$ before, $0 \mathrm{~min}$ after, and $13 \mathrm{~min}$ after the photobleaching at room temperature. An enlarged segment of the dendrite of the same neuron is presented in the lower panel. (B) A scheme illustrating fluorophore bleaching by the evanescent field. Only those fluorescently tagged receptors that are located in the close vicinity of the plasma membrane are bleached during prolonged TIRF illumination. (C) A typical plot of normalized fluorescence recovery after bleaching in the evanescent field. Pre-bleaching fluorescence $=100 \%$, post-bleaching

fluorescence $=0 \%$. Relative FRAP is measured as the steady-state level to which the fluorescence recovers.

\section{EFFECTS OF TEMPERATURE ON PERIMEMBRANE TURNOVER OF P2X3-DsRed RECEPTORS}

By changing the temperature from 21 to $29^{\circ} \mathrm{C}$, we found that the $\mathrm{P} 2 \mathrm{X} 3$ receptor turnover was strongly accelerated. Figure $3 \mathrm{~B}$ shows that at $29^{\circ} \mathrm{C}$ the fluorescence recovery was 3.5 times faster than at $21^{\circ} \mathrm{C}$ (time constant $0.6 \pm 0.09 \mathrm{~min}$ at $29^{\circ} \mathrm{C}$ versus $2.15 \pm 0.82 \mathrm{~min}$ at $21^{\circ} \mathrm{C}, P<0.05, n=16$ and $n=12$, respectively). Thus, at $29^{\circ} \mathrm{C}$ fluorescence recovery was largely complete in $<1$ min after photobleaching (Figure 3A). The calculated temperature dependence coefficient $\mathrm{Q}_{10}$ was 4.62 .

\section{ROLE OF VESICULAR TRAFFIC IN P2X3-DsRed RECEPTOR TURNOVER}

We have shown previously that Brefeldin A, a widely used inhibitor of the vesicular traffic, blocks the insertion of $\mathrm{P} 2 \mathrm{X} 3$ receptors into plasma membrane of sensory neurons (Fabbretti et al., 2006). Therefore, we used Brefeldin A to test whether vesicular trafficking mediated the strong effects of temperature on P2X3-DsRed perimembrane turnover. Figure 4 shows that Brefeldin A $(10 \mu \mathrm{g} / \mathrm{ml}$, $2 \mathrm{~h}$ pre-incubation) induced deceleration of $\mathrm{P} 2 \mathrm{X} 3$ receptors turnover at $29^{\circ} \mathrm{C}(n=15, P<0.05)$ but had no effect at room temperature $(n=5, P>0.05)$. Thus, in the presence of Brefeldin A, the rates of recovery after photobleaching became almost identical for 21 and $29^{\circ} \mathrm{C}$. As a result, $\mathrm{Q}_{10}$ decreased from 4.62 to 1.02 . These data indicated that cooling eliminates the Brefeldin A-dependent traffic thus decelerating $\mathrm{P} 2 \mathrm{X} 3$ receptor perimembrane turnover.

Since Brefeldin A had no effect on the P2X3 perimembrane turnover rate at $21^{\circ} \mathrm{C}$ (Figure $4 \mathrm{~B}$ ), we asked which mechanisms,
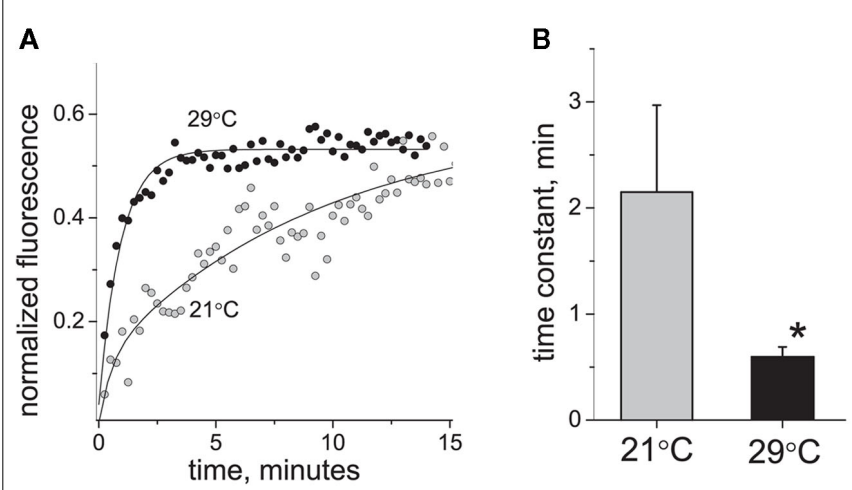

FIGURE 3 | Effect of temperature on P2X3 receptor turnover. (A) Typical examples of P2X3-DsRed fluorescence recovery traces at $21^{\circ} \mathrm{C}$ (tau $=3.5 \mathrm{~min}$ ) and $29^{\circ} \mathrm{C}$ (tau $\left.=0.9 \mathrm{~min}\right)$. (B) Averaged time constant of $\mathrm{P} 2 \times 3$ receptor recovery at $21^{\circ} \mathrm{C}(n=12)$ and $29^{\circ} \mathrm{C}(n=16)$. The asterisk denotes a significant difference at $P<0.05$.
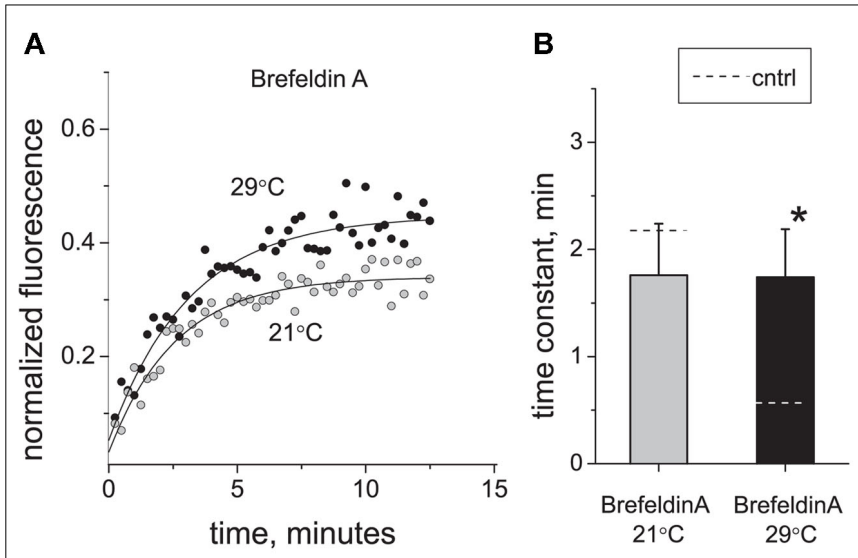

FIGURE 4 | Effect of vesicle traffic inhibition on P2X3 receptor turnover and its temperature sensitivity. (A) Typical examples of P2X3 receptor recovery traces at $21^{\circ} \mathrm{C}$ (tau $=2.5 \mathrm{~min}$ ) and $29^{\circ} \mathrm{C}$ (tau $=2.8 \mathrm{~min}$ ) after application of Brefeldin A $(10 \mu \mathrm{g} / \mathrm{ml})$. (B) Effect of Brefeldin A on the time constant of P2X3-DsRed fluorescence recovery after photobleaching. For comparison, control levels in (B) are shown as dotted lines. The asterisk indicates a significant difference from control values at $P<0.05$.

other than Brefeldin A-sensitive traffic, determined the rate of fluorescence recovery in TIRF-FRAP (Figure 4A). We reasoned that the rate-setting mechanism(s) of perimembrane turnover could be either (i) endosomal recycling or (ii) lateral diffusion of P2X3-DsRed receptors within plasma membrane. To test this, we employed an image analysis method (Pochynyuk et al., 2007) that allows distinguishing the molecules approaching basal plasma membrane from those "sliding" along the plasma membrane toward the evanescent field. This analysis revealed that the lateral diffusion of P2X3-DsRed, if any, did not contribute measurably to the perimembrane turnover either at 21 or $29^{\circ} \mathrm{C}$ (Figure A1 in Appendix). By ruling out the contribution from both Brefeldin A-sensitive traffic and lateral diffusion, we suggest that at room temperature endosomal recycling plays a central role. In contrast, 
at $29^{\circ} \mathrm{C}$ the contributions of endosomal recycling and lateral diffusion appear minor compared to that of Brefeldin A-sensitive traffic.

\section{INVOLVEMENT OF RhOA KINASE IN REGULATION OF P2X3 RECEPTOR TURNOVER}

Activation of RhoA kinase signaling has been suggested as an important factor in the initiation and maintenance of hyperalgesia caused by nerve injury and inflammation (Inoue et al., 2004; Tatsumi et al., 2005). RhoA is also implicated in regulation of various trafficking processes (for review, Ridley, 2001, 2006). To determine the contribution of RhoA kinase-dependent processes to trafficking of $\mathrm{P} 2 \mathrm{X} 3$ receptors, we applied the RhoA kinase inhibitor Y27632 $(2 \mu \mathrm{M})$ and found that it significantly decelerated the perimembrane turnover of $\mathrm{P} 2 \mathrm{X} 3$ receptors at $29^{\circ} \mathrm{C}$ (time constant increased from $0.60 \pm 0.09$ to $1.49 \pm 0.43 \mathrm{~min}, n=8$, $P<0.05$; Figure 5). In contrast, at room temperature Y27632 did not cause any significant changes in P2X3 perimembrane turnover rate (from $2.15 \pm 0.82$ to $2.42 \pm 0.6 \mathrm{~min}, P>0.05$ ). Due to selective deceleration at $29^{\circ} \mathrm{C}$, the $\mathrm{Q}_{10}$ coefficient decreased to a value of 1.96 in the presence of Y27632. These data suggest that elimination of the RhoA kinase control of receptor recycling plays a key role in cooling-induced deceleration of $\mathrm{P} 2 \mathrm{X} 3$ receptor trafficking toward the plasma membrane. Taken together, the data obtained with Brefeldin A and Y27632 indicate that the temperature sensitivity of perimembrane turnover of $\mathrm{P} 2 \mathrm{X} 3$ receptors is mediated by specific intracellular traffic mechanisms.

\section{COMPARISON OF TEMPERATURE EFFECTS AND REGULATORY MECHANISMS IN SOMA AND DENDRITES}

Due to distinct morphological features of somatic and dendritic compartments, such as different structure of the cytoskeleton, the mechanisms of perimembrane turnover in dendrites may be different from those in soma. Therefore, we compared the

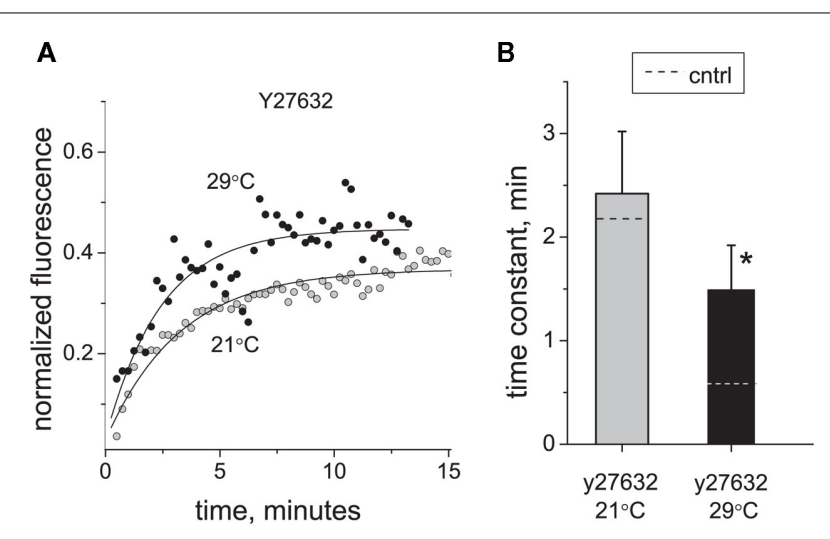

FIGURE 5 | Effect of RhoA kinase inhibition on P2X3 receptor turnover and its temperature sensitivity. (A) Typical examples of $\mathrm{P} 2 \mathrm{X} 3$ receptor recovery traces at $21^{\circ} \mathrm{C}$ (tau $=2.4 \mathrm{~min}$ ) and $29^{\circ} \mathrm{C}$ ( $\operatorname{tau}=2.1 \mathrm{~min}$ ) in the presence of Y27632. (B) Effect of RhoA kinase inhibitor Y27632 (2 $\mu \mathrm{M})$ on the time constant of $\mathrm{P} 2 \mathrm{X} 3$ receptors recovery after photobleaching. For comparison, control levels in $\mathrm{B}$ are shown with dotted lines. The asterisk indicates a significant difference from control values at $P<0.05$. temperature dependence and regulatory mechanisms of $\mathrm{P} 2 \mathrm{X} 3$ perimembrane turnover in dendrites versus soma. We observed a clear trend for the turnover in dendrites to be slower than in soma (Table 1), although this difference did not reach the statistical significance $(P=0.3)$. The temperature dependence of $\mathrm{P} 2 \mathrm{X} 3$ receptor turnover in dendrites was very strong, similarly to that observed in somatic regions $\left(\mathrm{Q}_{10}=4.20\right.$ in dendrites versus 4.62 in soma). The effects of RhoA kinase inhibition and vesicular traffic inhibition on the turnover rate at $29^{\circ} \mathrm{C}$ (but not at $21^{\circ} \mathrm{C}$ ) were also similar for soma and dendrites (Table 1). Taken together, neither temperature dependence nor mechanisms of regulation of perimembrane turnover of $\mathrm{P} 2 \mathrm{X} 3$ receptors appear to be different in soma versus dendrites.

\section{COMPARISON OF PERIMEMBRANE TURNOVER RATE FOR DIFFERENT CELL CULTURES AND RECEPTOR TYPES}

The $\mathrm{Q}_{10}$ of $\sim 4.5$ we observed for the perimembrane turnover rate of $\mathrm{P} 2 \mathrm{X} 3$ receptors is much higher than the $\mathrm{Q}_{10}$ values usually found in FRAP experiments with other biomolecules (1.5-2.5; Combs and Balaban, 2001). To test whether such high temperature sensitivity was typical also for other ligand gated channels, we transfected hippocampal neurons with the plasmid encoding for GFP-tagged AMPA-type glutamate receptors and measured the temperature dependence of their trafficking using the TIRF-FRAP assay. We found that AMPA receptor perimembrane turnover at $21^{\circ} \mathrm{C}$ had a time constant of $6.98 \pm 2.3 \mathrm{~min}(n=4)$ and was only slightly accelerated at $29^{\circ} \mathrm{C}\left(\mathrm{Q}_{10}\right.$ of 1.48$)$. This striking difference between AMPA and $\mathrm{P} 2 \mathrm{X} 3$ receptors indicates that the strong temperature sensitivity of recycling is a specific feature of P2X3 receptors. Furthermore, these data suggest that the high temperature sensitivity of $\mathrm{P} 2 \mathrm{X} 3$ receptors was not related to any technical peculiarities of our experimental setup.

Finally, we asked whether the unusual sensitivity of perimembrane recycling of $\mathrm{P} 2 \mathrm{X} 3$ receptor to temperature can be attributed to the expression machinery of hippocampal neurons. To address this, we applied the TIRF-FRAP method to P2X3-DsRed receptors expressed in HEK-293 cells and found that the rate of their perimembrane turnover at $29^{\circ} \mathrm{C}$ was $1.09 \pm 0.14 \mathrm{~min}(n=12)$, similar to that of P2X3-DsRed expressed in somata of cultured hippocampal neurons and nearly equal to those expressed in their dendrites. This observation indicates that the deceleration of $\mathrm{P} 2 \mathrm{X} 3$ receptor perimembrane turnover by cooling is likely to reflect an intrinsic feature of these receptors independent on the cell type they are expressed in.

Table 1 | Modulation of P2X3 receptors turnover in soma and dendrites at $29^{\circ} \mathrm{C}$ (the $21^{\circ} \mathrm{C}$ data are omitted for simplicity).

\begin{tabular}{lcc}
\hline & \multicolumn{2}{c}{ Time constant, $\mathbf{m i n}$} \\
\cline { 2 - 3 } & Soma & Dendrites \\
\hline Control $(n=16)$ & $0.6 \pm 0.09$ & $1.04 \pm 0.4$ \\
Y27632 $(n=8)$ & $\mathbf{1 . 4 9} \pm \mathbf{0 . 4 3 *}$ & $\mathbf{2 . 3 8} \pm \mathbf{0 . 9 6 *}$ \\
Brefeldin A $(n=15)$ & $\mathbf{1 . 7 4} \pm \mathbf{0 . 4 5 *}$ & $\mathbf{2 . 8 1} \pm \mathbf{0 . 5 1 *}$
\end{tabular}

Significant difference from control is shown in bold and marked with an asterisk. 


\section{DISCUSSION}

In the present study, we used the TIRF-FRAP technique to characterize for the first time the rate of $\mathrm{P} 2 \mathrm{X} 3$ receptor perimembrane turnover and its sensitivity to temperature. The main finding of our study is the unusually high temperature dependence of P2X3 receptor trafficking to plasma membrane. This traffic is RhoA kinase-dependent and has a $\mathrm{Q}_{10}$ coefficient of 4.6 at soma and 4.2 at dendrites. The dramatic decrease in the rate of perimembrane turnover caused by cooling to room temperature, taken together with the published evidence of a similarly strong temperature dependence of $\mathrm{P} 2 \mathrm{X} 3$ receptor resensitization, suggest a role of $\mathrm{P} 2 \mathrm{X} 3$ receptors in analgesic effects of hypothermia.

\section{CHOICE OF CELLULAR MODEL AND IMAGING TECHNIOUE}

We investigated P2X3 receptor trafficking in embryonic hippocampal neurons which do not express endogenous P2X3 receptors at this stage of development (Khakh et al., 2001) while offering the advantages of neuronal morphology and trafficking machinery. We opted against the use of primary trigeminal or dorsal root ganglion neurons expressing endogenous $\mathrm{P} 2 \mathrm{X} 3$ receptors in order to avoid interaction between native and overexpressed receptors. An additional reason for not using trigeminal or dorsal root ganglion neurons stems from their morphology in cultured conditions: only a minor fraction of basal plasma membrane of these neurons is located within the evanescent field (our unpublished observation).

Mechanisms of P2X3 receptor trafficking to plasma membrane were recently investigated using biotinylation and immunofluorescence techniques (Vacca et al., 2009). The authors described a rapid, agonist-dependent up-regulation of the membraneinserted pool of P2X3 receptors upon stimulation, thus revealing a highly dynamic nature of P2X3 trafficking. Lalo et al. (2010) have recently used live cell imaging and the conventional FRAP technique to demonstrate an important role of receptor trafficking in regulation of $\mathrm{P} 2 \mathrm{X} 1$ receptor responsiveness. Our data obtained here by means of an advanced imaging technique (TIRF-FRAP) provide further evidence of rapid regulation P2X receptor surface expression. We took advantage of the TIRF-FRAP method (Sund and Axelrod, 2000; Pochynyuk et al., 2007) to visualize the perimembrane pool of fluorescently tagged P2X3 receptors with a supra-optical vertical resolution of approximately $100 \mathrm{~nm}$. While we could not distinguish between membrane-inserted receptors and those located near the plasma membrane (e.g., in endosomes, secretory vesicles, or ER; Khiroug et al., 2009), the physical nature of the evanescent field ensures that those receptors that are located $>100 \mathrm{~nm}$ further away from plasma membrane (i.e., beyond the reach of evanescent field) are not affected by bleaching. Hence, TIRF-FRAP kinetics represented the turnover between proximal (perimembrane) and distal (cytosolic) pools of the receptors in a highly spatially resolved manner. This is one of the major advantages of TIRF-FRAP technique as compared to the conventional FRAP method, which measures the lateral diffusion and horizontal traffic of receptors in membrane or cytosol (Sund and Axelrod, 2000).

\section{P2X3 RECEPTOR TRAFFICKING VIA RhOA KINASE-DEPENDENT AND BREFELDIN A-SENSITIVE MECHANISMS}

The fungal antibiotic Brefeldin A has been used for a long time as the powerful inhibitor of intracellular trafficking (Pelham, 1991). We have previously found that this agent blocked the delayed CGRP-induced insertion of $\mathrm{P} 2 \mathrm{X} 3$ receptors in the membrane of trigeminal neurons in migraine-like states (Fabbretti et al., 2006; Giniatullin et al., 2008). The pronounced inhibitory effect of Brefeldin A on P2X3 receptor turnover exclusively at $29^{\circ} \mathrm{C}$ but not at room temperature as reported here suggests that cooling inactivates the Brefeldin A-sensitive trafficking of $\mathrm{P} 2 \mathrm{X} 3$ receptors from cytoplasmic pools into the plasma membrane.

In agreement with this notion, we found that RhoA kinase failed to affect the turnover of $\mathrm{P} 2 \mathrm{X} 3$ receptors at room temperature and that the specific inhibitor of RhoA kinase, Y27632 drastically reduced the $\mathrm{Q}_{10}$ coefficient for receptor turnover. RhoA kinase is known to be involved in trafficking of a variety of different membrane proteins such as Na,K-ATPase (Dada et al., 2007) or voltage sensitive potassium channels (Stirling et al., 2009). Moreover, RhoA kinase is implicated in initiation and maintenance of neuropathic pain (Tatsumi et al., 2005). Consistent with this, it has been shown that the RhoA kinase inhibitor Y27632 had the antinociceptive effect in several pain tests (Buyukafsar et al., 2006).

Taken together, our experiments have identified P2X3 receptor trafficking as a potential target for the analgesic effects of Y27632 and will help design antinociceptive drugs based on the mechanism of action identified here.

\section{MECHANISMS OF PERIMEMBRANE TURNOVER AND TIRF-FRAP DATA INTERPRETATION}

Which molecular mechanisms underlie perimembrane turnover of P2X3-DsRed receptors, and which of them render this turnover so sensitive to temperature? We hypothesize that there are mainly three contributors in perimembrane turnover: (i) trafficking from Golgi and/or endoplasmic reticulum to plasma membrane, (ii) endosomal recycling and (iii) lateral diffusion within plasma membrane. Close analysis of the imaging data suggests that the contribution of the lateral diffusion is negligible both at 21 and $29^{\circ} \mathrm{C}$ (Figure $\mathbf{A} 1$ in Appendix). Indeed, while temperature affects membrane viscosity and may, therefore, influence the mobility of membrane associated molecules, this only accounts for moderate $\mathrm{Q}_{10}$ values of 1.3-2.5 (Reits and Neefjes, 2001), which are substantially lower than the values reported in this study (4.6 for soma and 4.2 for dendrites). These findings indicate that the high perimembrane turnover rates require more than mere diffusion of $\mathrm{P} 2 \mathrm{X} 3$ receptors and involve highly temperature-sensitive enzymatic processes.

The relative contributions of trafficking and recycling to perimembrane turnover of $\mathrm{P} 2 \mathrm{X} 3$ receptors appear to vary dramatically with temperature. As suggested by the lack of effect of the traffic inhibitor Brefeldin A at $21^{\circ} \mathrm{C}$, endosomal recycling appears to be the rate-setting mechanism at lowered temperatures. At $29^{\circ} \mathrm{C}$, the situation is opposite: rapid, Brefeldin A-sensitive, and RhoA kinase-dependent trafficking largely determines the rate of P2X3 perimembrane turnover. Together, our findings suggest 
that trafficking of $\mathrm{P} 2 \mathrm{X} 3$ receptors from Golgi and/or endoplasmic reticulum is the most temperature-sensitive component of their perimembrane turnover. Endosomal recycling of $\mathrm{P} 2 \mathrm{X} 3$ receptors appears to be less sensitive to temperature and may contribute to the Brefeldin A- and Y27632-insensitive turnover.

\section{FUNCTIONAL IMPLICATIONS}

Extracellular ATP is one of the main endogenous algogens in the human body, and is released under many physiological and pathological conditions (Burnstock, 2006). P2X3 receptors are involved in transmission of inflammatory and cancer pain (Burnstock, 2000; Chizh and Illes, 2001; North, 2004), presumably due to the increased receptor's responsiveness to ATP. Accelerated receptor trafficking to plasma membrane has been suggested as the main mechanism of $\mathrm{P} 2 \mathrm{X} 3$ responsiveness enhancement in trigeminal neurons in migraine-like states (Fabbretti et al., 2006). The unusually high temperature sensitivity of P2X3 trafficking reported here may, along with resensitization, play a significant role in the enhancement of pain sensitivity during inflammation as body temperature rises. Conversely, cooling decreases the rate of insertion of $\mathrm{P} 2 \mathrm{X} 3$ receptors into the plasma membrane, thus providing a novel molecular basis for the commonly known analgesic effects of cooling. We propose that the extremely temperature-sensitive, RhoA kinasemediated P2X3 receptor trafficking mechanism is a promising target for developing new therapeutic strategies to counteract pain.

\section{MATERIALS AND METHODS DNA CONSTRUCTS}

The plasmid encoding the P2X3-DsRed protein (Grote et al., 2005) was a kind gift from Prof A. Zimmer (Bonn University, Germany). Plasmid encoding for GFP-tagged GluR-A receptors was kindly donated by Dr. Sarah Coleman and Prof. Kari Keinänen (University of Helsinki). This construct was verified by restriction mapping and by sequencing through all PCR derived parts as described previously (Khiroug et al., 2009).

\section{WHOLE-CELL PATCH-CLAMP RECORDINGS}

Whole-cell patch-clamp recordings (in voltage-clamp mode) were performed in HEK-293 cells transfected with P2X3-DsRed, untagged P2X3, and cultured sensory neurons from mouse trigeminal ganglion. Currents were recorded at the holding potential of $-60 \mathrm{mV}$ (for HEK-293 cells) or $-70 \mathrm{mV}$ (for neurons) using HEKA EPC-10 USB amplifier controlled with HEKA Patch Master software (HEKA Elektronik). Patch micropipettes (pulled from the Harvard Apparatus GC150F-10 glass, tip resistance of 3-5 M $\Omega$ ) were filled with a solution containing (mM): 130 $\mathrm{CsCl}, 5$ EGTA, $0.5 \mathrm{CaCl}_{2}, 5 \mathrm{MgCl}_{2}, 5 \mathrm{~K}_{2} \mathrm{ATP}, 0.5 \mathrm{NaGTP}$, and 10 HEPES ( $\mathrm{pH}$ adjusted to 7.2 with $\mathrm{CsOH}$ ). During recordings cells were superfused $(1.5-2 \mathrm{ml} / \mathrm{min}$ flow rate) at room temperature $\left(21-22^{\circ} \mathrm{C}\right)$ with standard extracellular solution containing (in $\mathrm{mM}$ ): $152 \mathrm{NaCl}, 2.5 \mathrm{KCl}, 10$ glucose, $2 \mathrm{CaCl}_{2}, 1$ $\mathrm{MgCl}_{2}, 10 \mathrm{HEPES}$ ( $\mathrm{pH}$ adjusted to 7.4 with $\mathrm{NaOH}$ ). $\alpha, \beta$-meATP $(10 \mu \mathrm{M}, 2 \mathrm{~s})$ was applied to the patch-clamped cell using rapid solution exchange system (RSC-200; BioLogic Science Instruments). Membrane current recording and drug application were synchronized using TTL trigger signals provided by the Patch Master software.

\section{PREPARATION OF HEK-293 CELLS TRANSFECTED WITH P2X3-DsRed RECEPTORS}

HEK-293 cells were routinely grown in DMEM (Invitrogen, Paisley, UK) supplemented with 10\% fetal bovine serum (Invitrogen, Paisley, UK) and $100 \mathrm{U} / \mathrm{ml}$ penicillin-streptomycin at $37^{\circ} \mathrm{C}$ in $5 \% \mathrm{CO}_{2}$. For transfection, 100,000 cells per well were plated (in 12 well plate) $12-24 \mathrm{~h}$ in advance. Fugene HD (Roche, Espoo, Finland) was used at ratio of $2 \mu \mathrm{l}$ Fugene $\mathrm{HD}$ per $1 \mu \mathrm{g}$ of DNA in $1 \mathrm{ml}$ of media. Twelve to sixteen hours before experiments cells were plated on cover-slips in $35 \mathrm{~mm}$ dish, 6580,000 cells per dish. Cells were used within 4 days of transfection.

\section{CULTIVATION OF PRIMARY TRIGEMINAL NEURONS}

Primary cultures of mouse trigeminal ganglion sensory neurons were prepared as previously reported (Simonetti et al., 2006), with some modification (Van Ryssen et al., 2009). Briefly, P10-12 C57BL/6J mice were anesthetized with $\mathrm{CO}_{2}$ and killed by decapitation. Ganglia were rapidly excised and enzymatically treated and dissociated in F12 medium (Invitrogen, Gibco, Cat. No. 31765) containing $0.25 \mathrm{mg} / \mathrm{ml}$ trypsin, $1 \mathrm{mg} / \mathrm{ml}$ collagenase, and $0.2 \mathrm{mg} / \mathrm{ml} \mathrm{DNAse} \mathrm{(Sigma)} \mathrm{at} 37^{\circ} \mathrm{C}, 1400 \mathrm{rpm}$ for $20 \mathrm{~min}$ using Thermomixer (Eppendorf). Cells were separated from debris by consecutive centrifugation and plated on polyL-lysine-coated $35 \mathrm{~mm}$ Petri dishes or $12 \mathrm{~mm}$ cover-slips in F12 medium containing $10 \%$ fetal calf serum and used $24 \mathrm{~h}$ later.

\section{PREPARATION AND TRANSFECTION OF RAT HIPPOCAMPAL NEURONS}

All experimental procedures were approved by the Animal Care and Use Committee, University of Helsinki. Cultured neurons were prepared from embryonic day 18 rat hippocampi. Hippocampi were dissociated with Papain solution $(10 \mathrm{U} / \mathrm{ml})$. The cells were plated at a density of $3 \times 10^{4}$ cells $/ \mathrm{cm}^{2}$ on glassbottomed Petri dishes (MatTek) pre-coated with poly-L-lysine and laminin $\left(1-2 \mu \mathrm{g} / \mathrm{cm}^{2}\right)$. Cultures were maintained in the $5 \%$ $\mathrm{CO}_{2} / 95 \%$ air atmosphere at $37^{\circ} \mathrm{C}$ in Neurobasal medium (Invitrogen; $\mathrm{pH}=7.4$ ) supplemented with $\mathrm{B} 27$ (Invitrogen), $0.5 \mathrm{mM}$ L-glutamine, 100 units/ml penicillin, and $100 \mu \mathrm{g} / \mathrm{ml}$ streptomycin. Medium was changed twice per week. Neurons were transfected after 6-10 days in vitro with construct using Lipofectamine 2000 (Invitrogen) according to the manufacturer's instructions. Lipofectamine 2000 was removed after $6-8 \mathrm{~h}$. Cells were analyzed 1-2 days after transfection. TIRF-FRAP experiments on neurons older than 12 days were not conducted as at these age neurons in our conditions do not directly attach to the glass surface (due to proliferating glia) making TIRF imaging much more complicated.

\section{FLUORESCENCE IMAGING}

For TIRF imaging experiments, cell-containing MatTek dishes were transferred to the CellR imaging system (Olympus Europe, Hamburg, Germany). The system was equipped with an automated filter wheel for excitation filters and with 488 and $532 \mathrm{~nm}$ (50 mW) DPSS lasers (Melles Griot, CA, USA) for TIRF imaging. 
Laser light with $532 \mathrm{~nm}$ wavelength was used for excitation of DsRed, and $488 \mathrm{~nm}$ for excitation of GFP. The microscope frame and all optical elements were maintained at two distinct temperature modes: with the temperature control incubator (Solent Scientific, Segensworth, UK) on and off. Images were collected with a CCD camera (Orca, Hamamatsu, Japan). In TIRF mode fluorescence was excited by the thin evanescent field formed above the glass substrate due to total internal reflection of the laser beam (attenuated to 5-10\%). Frames were acquired every $10-15 \mathrm{~s}$ to reduce bleaching. During the experiments, cells were continuously perfused using a peristaltic pump with a standard

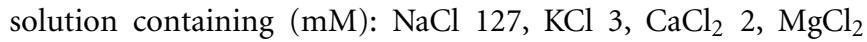
1.3, HEPES 20, glucose 10; $\mathrm{pH}$ was adjusted to 7.4 with $\mathrm{NaOH}$. To find out the influence of temperature level on $\mathrm{P} 2 \mathrm{X} 3$ receptor turnover, we conducted experiments in two experimental conditions: at 21 and $29^{\circ} \mathrm{C}$. Our experimental setup allowed us to maintain the temperature of perfusion solution stable at these two levels. With heating device on (Incubator temperature controller, Solent Scientific), temperature of perfusing solution was stabilized and maintained at $29^{\circ} \mathrm{C}$ and repeatedly measured during experiments using digital thermometer (Fisher scientific, accuracy $\pm 0.5^{\circ} \mathrm{C}$ ) placed in culture dish. In different set of experiments with temperature incubator off, temperature of perfusing solution was stabilized and maintained at $21^{\circ} \mathrm{C}$.

\section{DRUGS}

All chemical substances used in this study were purchased from Sigma-Aldrich (St. Louis, MO, USA), except for Brefeldin A and PMA which were purchased from Ascent Scientific (Bristol, UK). In experiments with Brefeldin A $(10 \mu \mathrm{g} / \mathrm{ml})$ cells were pre-treated in drug-containing solution for $2 \mathrm{~h}$ before the TIRF-FRAP experiment and Brefeldin A was present during the testing.

\section{REFERENCES}

Bobanovic, L. K., Royle, S. J., and Murrell-Lagnado, R. D. (2002). P2X receptor trafficking in neurons is subunit specific. J. Neurosci. 22, 4814-4824.

Burnstock, G. (2000). P2X receptors in sensory neurons. Br. J. Anaesth. 84, 476-488.

Burnstock, G. (2006). Historical review: ATP as a neurotransmitter. Trends Pharmacol. Sci. 27, 166-176.

Burnstock, G. (2007). Purine and pyrimidine receptors. Cell. Mol. Life Sci. 64, 1471-1483.

Buyukafsar, K., Yalcin, I., Kurt, A. H., Tiftik, R. N., Sahan-Firat, S., and Aksu, F. (2006). Rho-kinase inhibitor, Y-27632, has an antinociceptive effect in mice. Eur. J. Pharmacol. 541, 49-52.

Chizh, B. A., and Illes, P. (2001). P2X receptors and nociception. Pharmacol. Rev. 53, 553-568.

Combs, C. A., and Balaban, R. S. (2001). Direct imaging of dehydrogenase activity within living cells using enzyme-dependent fluorescence recovery after photobleaching (ED-FRAP). Biophys. J. 80, 2018-2028.

Cook, S. P., and McCleskey, E. W. (2001) Temperature dependence of sensory neuron P2X3 receptors. Society for Neuroscience Meeting, San-Diego.

Cook, S. P., Rodland, K. D., and McCleskey, E. W. (1998). A memory for extracellular $\mathrm{Ca} 2^{+}$by speeding recovery of $\mathrm{P} 2 \mathrm{X}$ receptors from desensitization. J. Neurosci. 18, 9238-9244.

Dada, L. A., Novoa, E., Lecuona, E., Sun, H., and Sznajder, J. I. (2007). Role of the small GTPase RhoA in the hypoxia-induced decrease of plasma membrane $\mathrm{Na}, \mathrm{K}$-ATPase in A549 cells. J. Cell Sci. 120(Pt 13), 2214-2222.

Derkach, V. A., Oh, M. C., Guire, E. S., and Soderling, T. R. (2007). Regulatory mechanisms of AMPA receptors in synaptic plasticity. Nat. Rev. Neurosci. 101-113.

\section{TIRF-FRAP (TOTAL INTERNAL REFLECTION FLUORESCENCE RECOVERY} AFTER PHOTOBLEACHING)

Upon obtaining a 3- to 5-min baseline, the fluorescence of membrane associated clusters was photobleached in TIRF mode by applying continuous illumination at $100 \%$ laser power for 60 120 s. For quantification of TIRF-FRAP experiments background level was subtracted prior to calculations. To ease the comparison between different experiments, mean pre-FRAP level of fluorescence intensity was accepted as $100 \%$, level just after bleaching as $0 \%$. We had to use quite long bleaching time due to relative stability of DsRed fluorophore: in absolute values the fluorescence after bleaching constituted about 50\% of pre-bleaching level. To calculate kinetic parameters the recovery was fit with a single exponent using Origin 6.0 software (Microcal). The degree of recovery (termed Relative FRAP, \%) was calculated as the plateau of the exponential function fitted to the fluorescence recovery curve.

Control experiments with neurons transfected with DsRed revealed strikingly different degree and pattern of recovery of TIRF-FRAP curve (Figure A2 in Appendix): TIRF-FRAP was almost complete at the time of measurement start and was therefore much faster than for P2X3-DsRed. This indicates that DsRed FRAP is not rate limiting step in our measurements. These data confirm specificity of P2X3-DsRed fluorescence recovery we observed.

\section{ACKNOWLEDGMENTS}

The plasmid encoding the P2X3-DsRed protein was a kind gift from Prof A. Zimmer (Bonn University, Germany). AMPA receptor plasmid kindly donated by Dr. Sarah Coleman and Prof. Kari Keinänen (University of Helsinki). The work was supported by the Academy of Finland (grants 135179 and 127150 for R. Giniatullin, 126321 for L. Khiroug), Finnish Cultural Foundation, and Center for International Mobility (CIMO) of Finland (for E. Pryazhnikov).

Fabbretti, E., D'Arco, M., Fabbro, A., Simonetti, M., Nistri, A., and Giniatullin, R. (2006). Delayed upregulation of ATP P2X3 receptors of trigeminal sensory neurons by calcitonin gene-related peptide. $J$. Neurosci. 26, 6163-6171.

Giniatullin, R., Nistri, A., and Fabbretti, E. (2008). Molecular mechanisms of sensitization of pain-transducing $\mathrm{P} 2 \mathrm{X} 3$ receptors by the migraine mediators CGRP and NGF. Mol. Neurobiol. 37, 83-90.

Grote, A., Boldogkoi, Z., Zimmer, A., Steinhauser, C., and Jabs, R. (2005). Functional characterization of $\mathrm{P} 2 \mathrm{X} 3$ receptors fused with fluorescent proteins. Mol. Membr. Biol. 22, 497-506.

Inoue, M., Rashid, M. H., Fujita, R., Contos, J. J., Chun, J., and Ueda, H. (2004). Initiation of neuropathic pain requires lysophosphatidic acid receptor signalling. Nat. Med. 10, 712-718.

Jarvis, M. F., and Kowaluk, E. A. (2001). Pharmacological characterization of
P2X3 homomeric and heteromeric channels in nociceptive signaling and behavior. Drug Dev. Res. 52, 220-231.

Khakh, B. S., Smith, W. B., Chiu, C. S., Ju, D., Davidson, N. and Lester, H. A. (2001). Activationdependent changes in receptor distribution and dendritic morphology in hippocampal neurons expressing P2X2-green fluorescent protein receptors. Proc. Natl. Acad. Sci. U.S.A. 98, 5288-5293.

Khiroug, S., Pryazhnikov, E., Coleman, S. K., Jeromin, A., Keinänen, K., and Khiroug, L. (2009). Dynamic visualization of membrane-inserted fraction of pHluorin- tagged channels using repetitive acidification technique. BMC Neurosci. 10, 141. doi: 10.1186/1471-220210-141

Khmyz, V., Maximyuk, O., Teslenko, V., Verkhratsky, A., and Krishtal, O. (2008). P2X3 receptor gating near normal body temperature. Pflugers Arch. 456, 339-347. 
Lalo, U., Allsopp, R. C., Mahaut-Smith, M. P., and Evans, R. J. (2010). $\mathrm{P} 2 \mathrm{X} 1$ receptor mobility and trafficking: regulation by receptor insertion and activation. J. Neurochem. 113, 1177-1187.

Latremoliere, A., and Woolf, C. J. (2009). Central sensitization: a generator of pain hypersensitivity by central neural plasticity. J. Pain 10, 895-926.

Liu, X. J., and Salter, M. W. (2010). Glutamate receptor phosphorylation and trafficking in pain plasticity in spinal cord dorsal horn. Eur. J. Neurosci. 2, 278-289.

McGaraughty, S., Wismer, C. T., Zhu, C. Z., Mikusa, J., Honore, P., Chu, K. L., Lee, C. H., Faltynek, C. R., and Jarvis, M. F. (2003). Effects of A-317491, a novel and selective $\mathrm{P} 2 \mathrm{X} 3 / \mathrm{P} 2 \mathrm{X} 2 / 3$ receptor antagonist, on neuropathic, inflammatory and chemogenic nociception following intrathecal and intraplantar administration. $\mathrm{Br}$. J. Pharmacol. 140, 1381-1388.

North, R. A. (2004). P2X3 receptors and peripheral pain mechanisms. J. Physiol. 554, 301-308.

Pelham, H. R. (1991). Multiple targets for brefeldin A. Cell 67, 449-451.

Pochynyuk, O., Staruschenko, A., Bugaj, V., LaGrande, L., and Stockand, J.
D. (2007). Quantifying RhoA facilitated trafficking of the epithelial $\mathrm{Na}^{+}$channel toward the plasma membrane with total internal reflection fluorescence - fluorescence recovery after photobleaching. $J$. Biol. Chem. 19, 14576-14585.

Reits, E. A., and Neefjes, J. J. (2001) From fixed to FRAP: measuring protein mobility and activity in living cells. Nat. Cell Biol. 3, E145-E147.

Ridley, A. J. (2001). Rho proteins: linking signaling with membrane trafficking. Traffic 2, 303-310.

Ridley, A. J. (2006). Rho GTPases and actin dynamics in membrane protrusions and vesicle trafficking. Trends Cell Biol. 16, 522-529.

Schmoranzer, J., Goulian, M., Axelrod, D., and Simon, S. M. (2000). Imaging constitutive exocytosis with total internal reflection fluorescence microscopy. J. Cell Biol. 149, 23-32.

Simonetti, M., Fabbro, A., D’Arco, M., Zweyer, M., Nistri, A., Giniatullin, R., and Fabbretti, E. (2006). Comparison of P2X and TRPV1 receptors in ganglia or primary culture of trigeminal neurons and their modulation by NGF or serotonin. Mol. Pain 2, 11 .
Stirling, L., Williams, M. R., and Morielli, A. D. (2009). Dual roles for RhoA/Rho-kinase in the regulated trafficking of a voltage-sensitive potassium channel. Mol. Biol. Cell 20, 2991-3002.

Sund, S. E., and Axelrod, D. (2000). Actin dynamics at the living cell submembrane imaged by total internal reflection fluorescence photobleaching. Biophys. J. 79, 1655-1669.

Tatsumi, S., Mabuchi, T., Katano, T., Matsumura, S., Abe, T., Hidaka, H., Suzuki, M., Sasajki, Y., Minami, T., and Ito, S. (2005). Involvement of Rho-kinase in inflammatory and neuropathic pain through phosphorylation of myristoylated alanine-rich C-kinase substrate (MARCKS). Neuroscience 131, 491-498.

Vacca, F., Giustizieri, M., Ciotti, M T., Mercuri, N. B., and Volonte, C. (2009). Rapid constitutive and ligand-activated endocytic trafficking of P2X3 receptor. J. Neurochem. 109, 1031-1041.

Van Ryssen, M. P., Avlonitis, N., Giniatullin, R., McDougall, C., Carr, J. L., Stanton-Humphreys, M. N., Borgström, E. L., Brown, C. T., Fayuk, D., Surin, A., Niittykoski,
M., Khiroug, L., and Conway, S. J. (2009). Synthesis, photolysis studies and in vitro photo release of caged TRPV1 agonists and antagonists. Org. Biomol. Chem. 7, 4695-4707.

Conflict of Interest Statement: The authors declare that the research was conducted in the absence of any commercial or financial relationships that could be construed as a potential conflict of interest.

Received: 29 September 2011; accepted: 01 December 2011; published online: 20 December 2011.

Citation: Pryazhnikov E, Fayuk D, Niittykoski M, Giniatullin $R$ and Khiroug $L$ (2011) Unusually strong temperature dependence of $P 2 X 3$ receptor traffic to the plasma membrane. Front. Cell. Neurosci. 5:27. doi: 10.3389/fncel.2011.00027 Copyright (c) 2011 Pryazhnikov, Fayuk, Niittykoski, Giniatullin and Khiroug. This is an open-access article distributed under the terms of the Creative Commons Attribution Non Commercial License, which permits non-commercial use, distribution, and reproduction in other forums, provided the original authors and source are credited. 


\section{APPENDIX}
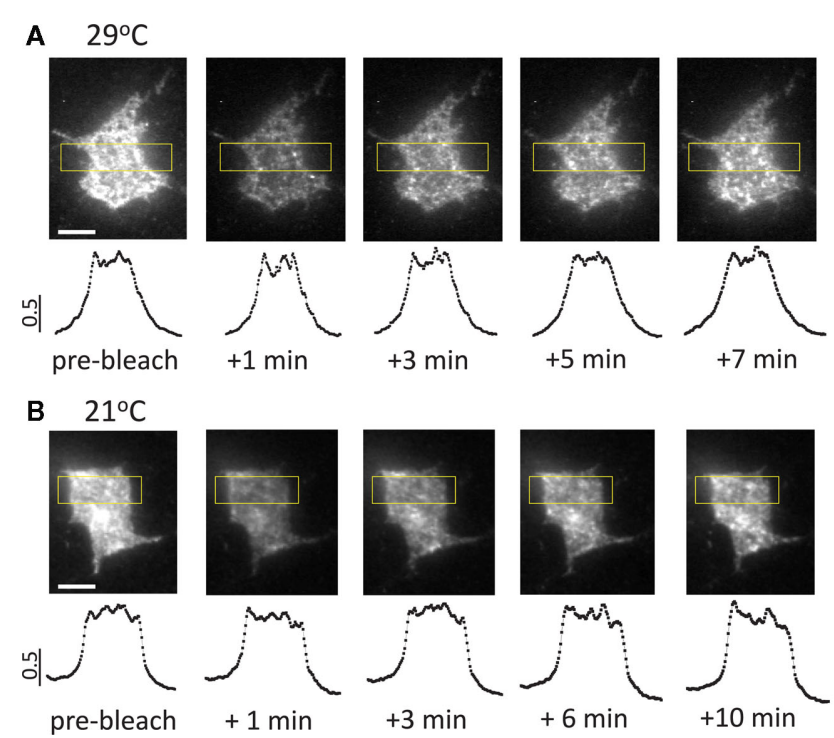

FIGURE A1 |Typical image sequences of fluorescence recovery after photobleaching at 21 and $29^{\circ} \mathrm{C}$ in somatic regions of transfected hippocampal neurons. (A) Fluorescence recovery after photobleaching at $29^{\circ} \mathrm{C}$. Note the homogenous distribution of the newly appearing fluorescent clusters contributing to fluorescence recovery. Lower panels show intensity profiles plotted against the long axis of the rectangular regions outlined in yellow. The plotted data were normalized to maximal intensity level. (B) Fluorescence recovery after photobleaching at $21^{\circ} \mathrm{C}$. Note similar spatial patterns at 21 and $29^{\circ} \mathrm{C}$, indicating that lateral diffusion of P2X3-DsRed plays a minimal (if any) role in fluorescence recovery (cf. Pochynyuk et al., 2007). Scale bars: $5 \mu \mathrm{m}$.
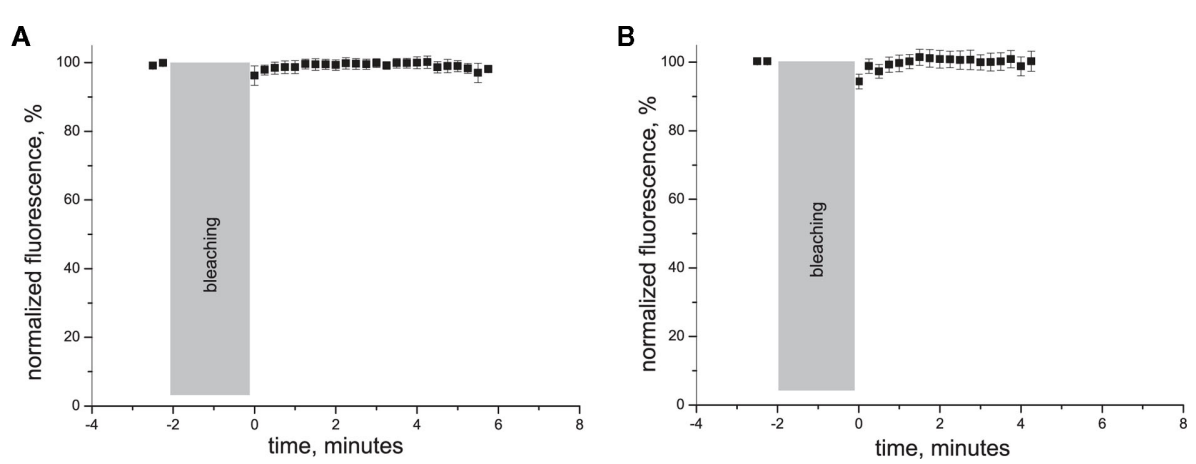

FIGURE A2 | Traces of normalized fluorescence recovery in experiments on hippocampal neurons transfected with plasmid encoding for cytoplasmic DsRed in soma (A) and dendrites (B). 